\title{
Variation in students' experience of learning in an accelerated, residential, study abroad setting in comparison to their traditional HE experience
}

\section{Jane MacKenzie}

University of Glasgow, UK

\section{Jane Pritchard}

University of Bristol, UK

\begin{abstract}
This study explores the variation in students' learning experiences of studying accelerated, residential courses during a four week study abroad option at an international study centre in the UK, compared with their experiences of learning at their home institution. In focusing on qualitative aspects of students' learning experiences in these settings, this study fills a gap in the accelerated course literature.
\end{abstract}

Analysis of a series of semi-structured interviews with students during their studies during the four week option revealed four distinctively different but related ways they described their experiences of the accelerated courses, compared with their home university learning experiences. These were: student sees the opportunity to learn; student feels safe; student takes learning risks; and student reconsiders learning. In traditional university settings there may be little variation in the forms and modes of teaching, learning and assessment in the student experience. One of the outcomes of this study is to suggest that in traditional university settings there is a place to explore increased opportunities for students to learn in different ways e.g. project and enquiry-based courses, innovative assessment using technology, group assessment as well as service learning courses, study abroad or work placement opportunities, and field-work across the disciplines. We believe that reviewing the academic year around different learning formats and duration of courses offers students (and teachers) opportunities to become increasingly aware of their own development and their own learning (and teaching). 
Keywords: student engagement; residential courses; awareness of learning; accelerated courses; study abroad.

\section{Introduction}

The purpose of this study is to explore the learning experience of students studying at a residential study centre in the UK during an intensive four-week term, in comparison to their experiences at the their home institutions. The four week summer term at Herstmonceux Castle in Sussex, home of Queen's University, Canada's International Study Centre, is unusual in Higher Education, and to the students in our sample, in that the courses are taught in an intensive or accelerated format, the study centre is residential, and they have opted to study abroad. It is this distinctiveness of learning experience which led us to explore the summer term using a phenomenographic methodology to look at the variation in our sample students' experiences. The outcomes of a parallel study exploring the experiences of staff teaching during the summer term is reported elsewhere (Pritchard and MacKenzie, 2011). We start here by looking at the three distinct aspects of the summer term: accelerated course delivery, residential learning and studying abroad.

\section{Accelerated formats}

A number of terms exist for what we call here accelerated courses; terms include compressed formats, time-shortened courses, intensive courses, January courses and one-at-a-time courses. These are courses which are nominally equivalent to semesterlong courses but are taught in a fraction of the time from 3-4 days, to as little as a single week. Whilst increasing numbers of colleges and universities are offering such accelerated courses (Daniel 2000), there has been little systematic research on the impact on students' learning in accelerated formats. Much of the research consists of quantitative, pseudo-experimental studies aimed at comparing the 'same' course delivered in a conventional format as opposed to an accelerated format. The consensus from this research would seem to be that students learn as much, or more, in an accelerated setting (Van Scyoc and Gleadon, 1993; Scott, 1995; Daniel, 2000). However, none of these studies involved random allocation of students to a specific format; thus the question remains whether those who choose to study the accelerated format are better motivated or academically prepared. Certainly, some staff involved in teaching these courses have 
reservations believing such courses are offered for the convenience of students but sacrifice academic rigour (Daniel, 2000; Scott, 2003). It has been argued that the required reflection is not possible where student-teacher contact time is reduced and that content must be sacrificed (Wolfe, cited Wlodkowski 2003). Conversely, other studies show that although teachers believe that learning is different in accelerated formats, it is still of high quality (Pritchard and MacKenzie, 2011). Scott (2003) concurs with this latter view arguing that while students do experience accelerated courses differently from traditional formats, the quality of the course is dependent on attributes other than time, including the teaching and assessment methods, the environment, and the quality of teaching. Students in this study report that when these attributes are present, accelerated courses can be 'powerful learning experiences' (Scott, 2003, p.34).

It has been suggested that students who opt for accelerated courses are likely to be more highly motivated and academically prepared than students opting for a more traditional format. This was not the case in a study by Seamon (2004). His quantitative comparison of outcomes of the same course taught in a traditional versus accelerated format took students' age, motivation and grade point average into consideration: students performed significantly better in the accelerated format regardless of these other factors. There was also evidence that students in the accelerated format performed better in terms of 'higher order' learning. However, the results of a follow-up evaluation indicated that the accelerated format was no better in terms of information retention in the long term (Seamon, 2004).

Wlodkowski (2008, p.3) states that the time students spend on learning is 'only a modest predictor of achievement'. He argues that other factors have an equal or greater impact; these include students' own motivation, their ability, and the quality of teaching. Successful learning on accelerated courses depends on the endeavour and diligence of the students (Wlodkowski and Ginsberg, 2010) but the curriculum must change to respond to the challenges of accelerated study. Scott's (2003) research indicates that students favour accelerated courses which emphasise depth over breadth; this is echoed by the students in this study and the staff in the parallel study (Pritchard and MacKenzie, 2011). She also reported that students favoured activities and assessments which enabled students to link classroom activities to their personal experiences. This issue of the personal or affective elements of learning can also be seen in the research on residential learning. Scholars have argued that 'the process of intense 'immersion' in the culture of learning and teaching 
in a residential setting provides a major learning experience for any course' (Morgan and Thorpe, 1993, p.74). Similarly, study abroad is often described as an immersive process (Wilkinson, 1998).

\section{Residential study}

There is a limited literature on learning in residential contexts and what does exist focuses mainly on adult and professional learning, rather than the higher education experiences of traditional university students like those in our study. It is believed that the curriculum, including course design and teaching and learning activities, have important roles to play in the success of residential courses, however, Bersch and Fleming (1997, p.52) maintain that for a high quality learning experience, it is also essential for learners to be able to 'detach themselves from daily realities and relax in an uninterrupted continuum of experience'. These two aspects: i) detachment from normal routines and responsibilities and ii) continuity of the learning experience, are what appears to ensure high quality learning and what makes residential learning distinct from more traditional, non-residential learning. Residential study encourages students to form close bonds and often results in a more 'intense' learning experience, where students are more likely to value their peers' experiences and opinions (Bersch and Fleming, 1997). The issue of detachment is echoed elsewhere (Schacht, 1960; Fleming, 1998). It has been suggested that when students are detached from the responsibilities of their normal lives they are better able to focus on their studies and are freer to be self-reflective (Bersch and Fleming, 1997; Cohen and Piper, 2000). Residential students living in situ have the opportunity to interact informally with staff and other students along with time for self-reflection over and above the planned-for curriculum; class is followed by discussion outside the classroom (Bersch and Fleming, 1997).

\section{Study abroad}

In addition to study at the Castle being in an accelerated, residential format, it is also an example of study abroad. The students at the Castle come mainly from Canada, though increasingly from other parts of the world, in order to study in the UK. With the current prioritisation of internationalising higher education, more students than ever are opting to study abroad, although Kitsantas writing in 2004 found that most US students who opt for study abroad choose to do so for only short periods of time, like the Castle summer term. 
Kitsantas (2004) reports that the reasons students give for studying abroad are to enhance their social lives as well as their understanding of the subject of study; in addition they also report the desire to improve their cross-cultural skills and awareness. Opting to study abroad has been reported to increase students' motivation towards learning and aid their intellectual development (Kuh and Kaufman, 1984).

\section{Rationale for current study}

One of the authors (JP) had first-hand experience of the Castle having previously taught the summer term; the other author (JM) had experience of accelerated, residential courses both as a student and teacher at a number of Open University summer schools, but had not taught or studied at the Castle. We both recognised the quality and intensity of the learning experience of our students in these two contexts appeared different to traditional university settings. Studying at the Castle during the summer term represents, for most of the students, a different way of engaging with higher education in terms of its accelerated, residential and study abroad context, and it is the contrast of this with their home studies that we wanted to explore further. After reviewing the literature in the area of intensive courses we identified a niche that the students learning within the Castle set-up could fit into. There was also a niche identified in a parallel study examining the Castle teachers' experiences relative to their home institution (Pritchard and MacKenzie, 2011).

This study explores the learning experiences of students attending the summer term at an accelerated, residential, study abroad setting, specifically, the International Study Centre at Herstmonceux Castle in Sussex (owned by Queen's University, Canada). Situated in and around $a 15^{\text {th }}$ Century castle, the study centre provides predominantly liberal artsbased courses for students from all years of the undergraduate degree. Students obtain credits recognised by their home institution. Most academic staff visit for one or more terms, although some are permanent. Most teach courses similar to those they teach at their home institutions, although some are unique to the Centre. Most students are from Canada, however increasingly other nationalities are represented, including the USA, Mexico and China. Summer term at the Castle is four weeks in duration with many of the staff and students coming only for that term. Students normally study two half-credit courses (the credit rating of an undergraduate degree from a Canadian university is 15-20 credits). Fees have been associated with these courses and for many their home 
university education. Whilst living quarters are located on campus close to the Castle, classes take place in the Castle itself. Students and staff eat in the same dining hall and socialise alongside each other in the on-site pub. Many of the courses have a British or European focus (e.g. The English Country House, British Landscape Art, Jacobean Shakespeare) and every course has associated field studies, trips to local museums, galleries and historic sites. Whilst most of the literature on accelerated and residential courses deals with courses taken by adults (over 25), the majority of students at the Castle summer term are traditional students, i.e. under 25.

\section{Methodology}

Given the dearth of research regarding the student learning experience in such contexts, we undertook the project with the explicit aim of examining: the variation in students' learning experiences in an accelerated, residential, study abroad context in comparison to their learning experiences in a traditional university setting. In order to explore this variation we have undertaken a phenomenographic study. Phenomenography is a qualitative research methodology within the interpretivist perspective (Crotty, 2003). It has at its core the aim of exploring the variation in the way a phenomenon is experienced and described; it assumes that there are a finite number of ways in which a phenomenon can be experienced and therefore described (categories of description) and through uncovering those ways the researcher can provide insights about the phenomenon (Marton and Booth, 1997). Categories of description are interrelated and this relationship, which emerges from the research process, is the outcome space. The phenomenon being investigated here is the experience of learning in an accelerated, residential, study abroad setting relative to learning in a traditional setting.

In total, 12 informed, consenting adult students studying at the Castle in the summer term of 2005 were interviewed; interviews were 45-60 minutes duration. Trigwell (2000) recommends a sample size of between 15 and 20 in phenomenographical research, however, given that the entire student population at the Castle at that time was approximately 50, the 12 participants represent a sizeable proportion of that population and we believe were sufficient to capture the full variation of experience. Each interview consisted of questions aimed at allowing students to describe their experiences of the 
Castle in relation to their home institution. The interviews were digitally recorded and transcribed verbatim, and the participant identities were anonymised.

The interview transcripts represent a pool of ways in which interviewees describe their experience; the descriptions are not ascribed to the individual. The authors carried out an initial reading and analysis of the interview transcripts independently and then met to discuss the categories of description and the students' words ascribed to each category. Each category of description has a process aspect ('how' the students describe aspects of the Castle relative to their home institutions) and an outcome aspect ('what' the students ascribe this process means). The analysis was an iterative process; the analysis of transcripts followed by discussions of categories of description occurred several times until the hierarchical relationship between categories (outcome space) was revealed. The analysis was an iterative process; the analysis of transcripts followed by discussions of categories of description occurred several times until the hierarchical relationship between categories (outcome space) was revealed. The categories were formalised by using illustrative quotes from the interview transcripts - again this was an iterative process where quotes are trialled in other categories to ensure they cannot appear in two places this would render the categories not discrete. After several attempts at this process both individually and together, a coherent and complete analysis of the interviews is arrived at with discrete categories of description that are supported by illustrative quotes from the interviews. These two steps of coding and discussion, termed as coder checking and dialogic checking by Akerlind (2005), have been recommended to enhance the reliability of the outcome space.

We start by describing the outcome space of this research and then present the categories of description of students' learning at the Castle summer term, supported by illustrative quotes.

\section{Results}

The outcome space is shown in Table 1. There are four categories of description within the outcome space arranged in a hierarchical relationship. These are: student sees the opportunity to learn; student feels safe; student takes learning risks; student reconsiders learning. Each category is a prerequisite to experiencing a category higher in the 
hierarchy, with the last category being highest in the hierarchy. For instance, a student will not experience 'student takes learning risks' without experiencing 'student feels safe', and so on.

Table 1. Outcome space for whole study.

\begin{tabular}{|l|l|l|}
\hline Category of experience & $\begin{array}{l}\text { HOW (the process) } \\
\text { aspects }\end{array}$ & $\begin{array}{l}\text { WHAT (the outcome) } \\
\text { aspects }\end{array}$ \\
\hline $\begin{array}{l}\text { A student sees } \\
\text { opportunity to learn }\end{array}$ & $\begin{array}{l}\text { Attributes of new } \\
\text { environment }\end{array}$ & Space to learn \\
\hline B Student feels safe & Student knows teacher & Being part of something \\
\hline $\begin{array}{l}\text { C Student takes } \\
\text { learning risks }\end{array}$ & Safe-risk taking & Student as explorer \\
\hline $\begin{array}{l}\text { D Student reconsiders } \\
\text { learning }\end{array}$ & The process of learning & The purpose of learning \\
\hline
\end{tabular}

\section{Category A: Student sees opportunity to learn}

In this category, students describe the Castle as an opportunity to learn in a new and distinct way (see Table 2 for quotes from the interviews that illustrate this category). 'How' the students recognise and describe this is in terms of attributes of the Castle itself, which diverge from the students' normal learning experience. First, the Study Centre is unusual in that it is set in a $15^{\text {th }}$ Century castle; for the students that in itself is an attraction: 'I mean how often do you get to come to a castle?' The summer term also represents an opportunity to study in Europe and students identified with the idea of a European holiday. However, students recognised other benefits. Since all courses include field studies, students have an opportunity to visit parts of Britain that are closely linked to their chosen subject(s) of study. The summer term also requires a relatively low investment in terms of time away from their normal studies and/or home commitments. Students had certain expectations about the summer term - that it would be more focused and that classes would be small. All of these elements contribute to the students experiencing the Castle as a distinctive experience. Overall, 'what' this represents for the students is a space to learn in a new and intense way. The experience was often described metaphorically, for example, as a summer camp, retreat or orientation week. The students recognised that 
they were engaged in a new type of experience; it was described as relaxed or laid back and, despite the fact that this was an accelerated term, students described having 'time' to engage with their studies.

Table 2. Student sees opportunity to learn (Category A) - quotes from students.

\begin{tabular}{|c|c|}
\hline $\begin{array}{l}\text { HOW (the process) aspect } \\
\text { Physical attributes of new environment }\end{array}$ & $\begin{array}{l}\text { WHAT (the outcome) aspect } \\
\text { Space to Learn }\end{array}$ \\
\hline $\begin{array}{l}\text { We get to see a real physical example } \\
\text { about what's being talked about, and for so } \\
\text { often, we're, we're, at my home university, } \\
\text { we read about people and places and things } \\
\text { and we have to kind of imagine what that } \\
\text { would be like. } \\
\text { I thought it would be an interesting } \\
\text { experience...the summer programme is } \\
\text { only four weeks long, so you get, it's a very } \\
\text { concentrated, and it's nice weather, nice } \\
\text { time to come. }\end{array}$ & $\begin{array}{l}\text { It doesn't seem as em, staid or stuffy as } \\
\text { some university classes can seem, so it's } \\
\text { eh, it's just a good atmosphere, a good sort } \\
\text { of laid back, easy to learn kind of place... } \\
\text { It gave me time to just look at two things } \\
\text { specifically...in a very concentrated way } \\
\text { and...I've been at time...I took six courses } \\
\text { the whole year, so at times my focus was } \\
\text { split up in so many different ways. But this } \\
\text { way, well like concentrate on it, and I think } \\
\text { I learn a lot more about it, since it was so } \\
\text { concentrated I could...um, I didn't have } \\
\text { more time to think about it, but I had more } \\
\text { focus. }\end{array}$ \\
\hline
\end{tabular}

\section{Category B: Student feels safe}

The second category of description in the outcome space is that the student feels safe (see Table 3 for quotes from the interviews that illustrate this category). The way in which students describe 'how' they feel safe is that they 'know their teacher' in contrast with their experiences at their home institutions. Students expressed surprise at the close proximity of staff and students both in and out of the classroom. Students described how they'd 'never talked to their professor' at home in contrast to their Castle experience. There was also recognition that their teachers had chosen to teach at the Castle and were therefore highly engaged and motivated with regards to their teaching. Teachers were also described as caring about their students and building relationships with them. This 
translates into 'what' the students describe: that they are valued as individuals and, with each other and their teachers, they are engaged in a shared endeavour. Students described feeling obligated to get to know people and the value of 'living and doing' with the same small group of people. The Castle is experienced as a more level, less hierarchical structure than their home institutions.

Table 3. Student feels safe (Category B) - quotes from students.

\begin{tabular}{|c|c|}
\hline $\begin{array}{l}\text { HOW (the process) aspect } \\
\text { Student knows teacher }\end{array}$ & $\begin{array}{l}\text { WHAT (the outcome) aspect } \\
\text { Feeling part of something }\end{array}$ \\
\hline $\begin{array}{l}\text { I have an expert who is accessible and I } \\
\text { think that's probably one of the most } \\
\text { important things... my professor is } \\
\text { accessible at breakfast, at coffee break, at } \\
\text { Iunch, at dinner, on field studies and during } \\
\text { classes is available to explain as much } \\
\text { explanation as I need about a particular } \\
\text { topic...that's not always possible when } \\
\text { there's two, three or four hundred people in } \\
\text { your class... } \\
\text { Maybe it's because the professor chose to } \\
\text { come here, and to teach here...but they } \\
\text { seem to be very interested and they are } \\
\text { very involved in what they are doing. }\end{array}$ & $\begin{array}{l}\text { Because I think that you get to like build a } \\
\text { relationship like outside of the classroom, } \\
\text { and I don't know, I think that's more } \\
\text { important, because then it's not like such, } \\
\text { as like a student...like teacher relationship. } \\
\text { There isn't necessarily such a big divide } \\
\text { between ... you know professor and } \\
\text { students you know. Everything is more } \\
\text { equal, more level, just generally more } \\
\text { relaxed, and comfortable. }\end{array}$ \\
\hline
\end{tabular}

\section{Category C: Student takes learning risk/s}

The third category of description is that at the Castle the student takes learning risks (see table 4 for quotes from the interviews that illustrate this category). The Castle was seen as a place where it was acceptable to take risks. The short term and the extra-curricular nature of the experience were liberating for most students. In terms of how the students ascribed meaning to this category of description, they described how the location of the Castle encouraged them to undertake courses related to the geographical area that they would not normally have studied. Some students had the option of taking elective courses 
in their degree programme and often opted to undertake courses far from their major area of study; some were studying for no credits. The meaning ascribed to this was the 'student as explorer'. Students were learning for learning's sake, taking risks in new areas and having 'fun'. They were stepping up to the challenge of the new in this supportive environment.

Table 4. Student takes learning risks (Category C) - quotes from students.

\begin{tabular}{|c|c|}
\hline $\begin{array}{l}\text { HOW (the process) aspect } \\
\text { Safe-risk taking }\end{array}$ & $\begin{array}{l}\text { WHAT (the outcome) aspect } \\
\text { Student as Explorer }\end{array}$ \\
\hline $\begin{array}{l}\text { I had to learn... most of the commonly } \\
\text { used sociology terms over a short period } \\
\text { of time and become proficient with } \\
\text { them... which is fine, because you } \\
\text { challenge yourself to be able to do so. } \\
\text { Um, I chose Shakespeare, actually just } \\
\text { because I'm really interested, I took a } \\
\text { course on it at school last year, so l'm } \\
\text { actually not getting credit for it. }\end{array}$ & $\begin{array}{l}\text { I want to just kind of like get away from that } \\
\text { and try like new things here. } \\
\text { They would be fun and interesting and } \\
\text { something I would probably never take } \\
\text { back at home, so I thought I'd give it a try. }\end{array}$ \\
\hline
\end{tabular}

\section{Category D: Student reconsiders learning}

The fourth and highest category in the outcome space is student reconsiders learning (see table 5 for quotes from the interviews that illustrate this category). There were many descriptions by students of the impact the Castle had on the way they considered their learning. The 'how' aspect of this category included descriptions of field studies; these were seen as encouraging a more exploratory approach. The design of curricula and the small classes afforded more discussion or 'conversation' in learning and this was believed to enhance the quality of learning. Students also recognised the intensity that studying in this accelerated format achieved. Meeting several times a week brought a 'freshness' to the way they approached their learning. The 'what' outcome of this category of description is that the students reconsidered the purpose of learning. Students described rediscovering the 'joy of learning' or having their interest in a past area of study rekindled. Students described being more open to new learning experiences, of discovering, through 
their engagement with learning at the Castle, a new found independence, of taking back to their own disciplines what they'd learned. They valued the interdisciplinary experience and expressed views relating to the purposes of learning itself - self-fulfilment.

Table 5. Student reconsiders learning (Category D) - quotes from students.

\begin{tabular}{|c|c|}
\hline $\begin{array}{l}\text { HOW (the process) aspect } \\
\text { The process of learning }\end{array}$ & $\begin{array}{l}\text { WHAT (the outcome) aspects } \\
\text { The purpose of learning }\end{array}$ \\
\hline $\begin{array}{l}\text { The level of debate rises...considerably, } \\
\text { because... we're fairly well versed in our } \\
\text { own disciplines, but we have to get our } \\
\text { head around somebody else's discipline, I } \\
\text { think that's maybe an intentional } \\
\text { challenge. } \\
\text { It meant that it was more you know sort of } \\
\text { learning all the way instead of just sort of } \\
\text { listening and soaking up a little bit here } \\
\text { and there and trying to learn everything } \\
\text { the night before the exam. } \\
\text { I cannot go and research an entirely new } \\
\text { discipline, so I have to take the information } \\
\text { and apply it to what I know, so that also } \\
\text { forces me to become more deeply } \\
\text { engaged in my own discipline, because I } \\
\text { have to go back and say what did I learn } \\
\text { about this? }\end{array}$ & $\begin{array}{l}\text { What I am learning will be associated with } \\
\text { the personal experience and just thinking } \\
\text { about my personal experience will make } \\
\text { me think about what I learned here... it's by } \\
\text { association and the way my brain is } \\
\text { working. }\end{array}$ \\
\hline
\end{tabular}

\section{The four categories in context}

It is logical to presume that the environment and context in which students learn have an impact on how they experience that learning, and we postulate that any students engaged in study at the Castle will arrive at least at the first category of description: the Castle as an 
opportunity to learn even if they do not arrive at the conceptions further up the hierarchy. Bersch and Fleming (1997) also contend that locale impacts on learners' experiences. In their study of a residential course for adult education faculty held on Yukon Island, Alaska, they report that the beautiful rural setting provides 'a multisensory experience that seems to heighten learning and magnify feelings' (Bersch and Fleming, 1997, p.54). Herstmonceux Castle also provides a visually pleasing setting. It is surrounded by Elizabethan gardens and parklands and comes complete with moat and drawbridge. Alongside this unique locale, the students at the Castle summer term are studying in an accelerated format, investing only four weeks of their time, and the Castle represents an opportunity to study abroad in a structured setting. Therefore study at the Castle is distinct from their home studies in many ways and this offers students a new and distinct learning opportunity.

Our second category of description is student feels safe. Central to the feelings of safety is what is described as 'student knows teacher'. The participants in this study expressed this in a number of ways; they reported that their teacher knew their name and that the teacher was constantly accessible, available to talk with enthusiasm about the topic of study. Students also recognised and valued the commitment of their teachers. They were aware that, like them, their teachers had chosen to teach at the Castle, to leave their daily responsibilities (research, family) behind; this increased feelings of being engaged in a joint endeavour with other students and teachers. Certainly the literature supports the view that students value commitment from teachers (Andrews et al., 1996; Jenkins and Speck, 2007). As Morgan and Thorpe (1993, p.75) writing of residential learning state, it:

brings together people whose only ostensible purpose for being together is their wish to learn the subject, and thus 'the subject' in some shape of form in never far from being the overt topic of all the dialogues taking place throughout the period of residence.

These feelings of safety and being engaged in a joint endeavour leads to our third category: student takes learning risks. The students have already made an investment when they opt to study at the summer term, both financially and in terms of their time. Many students expressed the challenge of studying accelerated courses, in many cases of delving into a brand new area of study. We argue that this risk taking is only possible and only recognised if students feel safe and part of something. Yorke and Knight (2004, p.36) 
make a case for the value of risk taking in learning 'In a society in which complex learning and employability are officially desired outcomes of the educational process, a higher education should surely not prompt students to avoid complexity and the taking of risks in their learning'. We agree; students should be encouraged and supported to be exploratory in their learning and take risks, although encouraging such approaches would be unethical if students are not appropriately supported. As Walker et al. (2006, p.257) put it: 'exposing learners to situations that favour risk and uncertainty without the trust and security of a well-managed classroom may have the adverse effect, and lead to disengagement and ultimate withdrawal for some learners'. We believe that the Castle summer term does expose students to some uncertainty and risk but our data suggests that the students trust their teachers sufficiently to feel supported in taking these risks. Further, we would argue that exposing learners to these 'risky situations' or novel ways of learning in an exciting yet safe environment is essential if we wish our learners to consider their learning differently, leading to our fourth category of description: student reconsiders learning.

It is hardly surprising that learning at the Castle was experienced by the students in this study as different to their home experiences, however, our findings indicate that the opportunities afforded by the Castle summer term, with its accelerated, residential and study abroad context, enabled at least some of the students in our study to go beyond recognising it as a different experience and to consider their own approach to learning and even the purposes of learning at university. The students described learning for its own sake rather than to pass assessments, to rediscover the pleasure afforded by learning and to see learning as part of their lived experience; the students' awareness of learning was changed.

There has been much debate about the quality of learning experienced in accelerated formats; our results indicate that study at the Castle summer term is experienced as a different but high quality experience. This is echoed by the experiences of those that teach the summer term (Pritchard and MacKenzie, 2011); this parallel study found that teachers also recognised the distinctiveness of the Castle context as offering them space to consider their teaching in depth and more, to reconsider the purpose of, and their role in, higher education. 


\section{Implications in the wider HE context}

We are cautious of over-interpreting our findings. Our study involves a small number of students during a single term in an accelerated, residential, study abroad setting. It is possible that the students who participated in this study are not wholly representative of the students who study during the summer term; we do not believe this is the case. Certainly, the students who chose to study there are a self-selected group. The majority of students were from the Study Centre's home institution, Queen's University, but these represent only a small proportion of those studying back home in Canada. Travelling to Europe to study for the equivalent of one credit is expensive and therefore not accessible to all students. However, paying fees for their higher education is commonplace for the North American students attending the summer school, although full or partial scholarships are available to some students for their home studies and towards this study abroad option. It may be that those who choose to do so, in addition to having the financial (and family commitment) freedom to attend, are also highly motivated and self-aware which might lead to a skewing of our data set. Certainly many expressed the view that they were coming to learn at the Castle for a different experience; perhaps not all students wish to have a 'different' experience.

The Castle is an uncommon learning context in its immersive qualities brought about by the three co-existing aspects of: accelerated, residential and study abroad learning. Our findings show that the students' Castle experience brings their perceptions of and approaches to learning to the fore. Implicit in this discussion is that this enhanced awareness of learning is by definition a 'good thing' and we make no apology for that. Too often in higher education today students equate learning with passing exams, getting the grades and getting the job. Learning for the sake of learning or for the pleasure it endows is at the forefront of much of the lifelong learning debate. We believe that becoming more aware of one's own learning will make one a better and more successful learner; whatever successful might mean. Also, in order for students to become the critical and ethical citizens we often claim is what characterises graduates, surely it is important for students to be aware of not only their own learning, but also the purpose of higher education. If so, we need to give students appropriate opportunities within our educational processes to develop such awareness about their own learning and to discern the purposes of higher education for themselves; how could this be brought about? 
Kuh and Kaufman (1984, p.2) state that 'student development occurs in response to novel situations and ideas which are difficult to assimilate given the student's present 'world view". Students must learn to develop new responses to the situation. Marton and Trigwell (2000, p.387) state that there can be 'no learning without discernment and there is no discernment without variation'. Central to their thesis is that only through experiencing a phenomenon in a variety of ways can that phenomenon be discerned and understood (Marton and Trigwell, 2000, p.386):

The discernment or experience is always the discernment of variation or the experience of difference. Darkness can only be experienced as a contrast to experienced (or imagined) light. You cannot experience greenness without the experience of other colours; without variation in colours, the very idea of colour cannot exist. If the level of happiness, or sorrow, never varied within individuals, nor differed between individuals, then happiness, and sorrow, would cease to exist.

Currently in higher education, many of our learning and teaching practices can be formulaic. Our courses are increasingly modularised and our responses to larger class sizes is to teaching 'efficiently' through lecture based courses, prescribed small group activities and standardised assessment methods. It is possible for students to experience very little variation in the ways of learning and methods of teaching throughout the three or four years of their degree, and we argue that this must result in obstructing awareness of their own learning. We believe our study demonstrates that the students at the Castle have experienced learning in a different and distinct context relative to their home studies and have thus experienced a meaningful variation in their own experiences of learning, leading to greater awareness of how and why they learn. Without such variation that awareness would be diminished. Marton and Trigwell (2000) argue that the experience of variation must occur regardless of the educational processes evoked and the subject of study; students must be given opportunities to see things in different ways. What is crucial is that students experience variation in learning by learning in different contexts.

\section{Conclusions}

We have argued that since awareness of variation is necessary for learning to occur, then variation in learning experiences is necessary for students to be aware of their own 
approach and conceptions of learning. We do not suggest that for this awareness to take place it is essential that students are immersed in accelerated or residential or study abroad experiences; not all students can spend four weeks studying in a $15^{\text {th }}$ Century castle. Perhaps only one of these elements would be sufficient for variation in learning to be discerned and perhaps other experiences could substitute for these. We would propose that experiencing learning in a sufficiently distinct context to their 'normal' context will result in students recognising the opportunities for learning that experience offers - i.e. the first category in our outcome space. Ultimately, we would wish to see our students having opportunities to enable them to reach the fourth category: to reconsider learning itself. However, to reach the fourth category of description in our outcome space requires the middle two categories: students need to feel safe in their learning and must be supported to taking learning risks. Only then will they acquire what we believe should be an essential feature of higher education: greater awareness of their own learning and the purpose of higher education itself. Currently, there may be little variation in the forms and modes of teaching, learning and assessment in the student experience. There is a current push within higher education to innovate. One of the outcomes of this may be increased opportunities for students to learn in different ways e.g. project and enquiry-based courses, innovative assessment using technology, group assessment as well as service learning courses, study abroad or work placement opportunities. These opportunities, we believe, offer students opportunities to become increasingly aware of their own development and their own learning.

\section{Acknowledgements}

The authors would like to thank all the staff at the Castle for their contribution to this work. We would also like to thank Professor Bob Matthew for his encouragement and welcome comments and Lucinda Dempsie for transcribing all the interviews.

\section{References}

Åkerlind, G.S. (2005) 'Variation and commonality in phenomenographic research methods', Higher Education Research and Development, 24(4), pp. 321-334. 
Andrews, J., Garriso, D.R. and Magnusson, K. (1996) 'The Teaching and learning transaction in Higher Education: a study of excellent professors and their students', Teaching in Higher Education, 1(1), pp. 81-103.

Bersch, G. and Fleming, J.A. (1997) 'Residential workshops', New Directions for Adult and Continuing Education, 76, pp. 51-58.

Cohen, J.B. and Piper, D. (2000) 'Transformation in a residential adult learning community', in Mezirow, J. and Associates (ed.) Learning as transformation: critical perspectives on a theory in progress. San Francisco: Josey-Bass, pp. 205-228.

Crotty, M. (2003) The foundations of social research: meaning and perspective in the research process. London: SAGE.

Daniel, E.L. (2000) 'A review of time-shortened courses across disciplines', College Student Journal, 34(2), pp. 298-308.

Fleming, J.A. (1998) 'Understanding residential learning: the power of detachment and continuity', Adult Education Quarterly, 48(4), pp. 260-271.

Jenkins, C.R. and Speck, B.W. (2007) "I'm in their corner': caring as foundational to effective teaching', Journal on Excellence in College Teaching, 18(2), pp. 41-60.

Kitsantas, A. (2004) 'Studying abroad: the role of college students' goals on the development of cross-cultural skills and global understanding', College Student Journal, 38(3), pp. 441-452.

Kuh, G.K., and Kauffman, N.F. (1984) The impact of study abroad on personal development of college students. Bloomington, IN: Indiana University School of Education.

Marton, F. and Booth, S. (1997) Learning and awareness. New Jersey: Lawrence Erlbaum. 
Marton, F. and Trigwell, K. (2000) 'Variatio Est Mater Studioru', Higher Education Research and Development, 19(3), pp. 381-395.

Morgan, A. and Thorpe, M. (1993) 'Residential schools in open and distance education: quality time for quality learning?', in Evans, T. and Nation, D. (eds.) Reforming open and distance education. London: Kogan-Page, pp. 72-87.

Pritchard, J. and MacKenzie, J. (2011) 'The variation in academics' experiences of teaching in an intense study centre compared with their traditional university settings', Journal of Further and Higher Education, 35(3), pp. 339-352.

Schacht, R.H. (1960) Weekend learning in the United States. Brookline, Mass: Center for the Study of Liberal Education for Adults.

Scott, P.A. (1995) 'Learning experiences in intensive and semester-length classes: student voices and experiences', College Student Journal, 29(2), pp. 207-213.

Scott, P.A. (2003) 'Attributes of High-Quality Intensive Courses', New Directions for Adult and Continuing Education, 97, pp. 29-39.

Seamon, M. (2004) 'Short- and long-term differences in instructional effectiveness between intensive and semester-length courses', Teachers College Record, 106(4), pp. 852-874.

Trigwell, K. (2000) 'Phenomenography: discernment and variation', Improving Student Learning, 7, pp. 75-85.

Van Scyoc, L. and Gleason, J. (1993) 'Traditional or intensive course lengths? A comparison of outcomes in Economics learning', Journal of Economics Education, 24(1), pp. 15-22.

Walker, C., Gleaves, A. and Grey, J. (2006) 'Can students within higher education learn to be resilient and, educationally speaking, does it matter?', Educational Studies, 32(3), pp. 251-264. 
Wilkinson, S. (1998) 'On the nature of immersion during study abroad: some participants' perspectives', Frontiers: The Interdisciplinary Journal of Study Abroad, 4, pp. 121138.

Wlodkowski, R.J. (2003) 'Accelerated learning in colleges and universities', New Directions for Adult and Continuing Education, 97, pp. 5-15.

Wlodkowski, R.J. (2008) Enhancing adult motivation to learn: a comprehensive guide for teaching all adults. $3^{\text {rd }}$ edn. San Francisco: Jossey-Bass.

Wlodkowski, R.J. and Ginsberg, M.B. (2010)Teaching intensive and accelerated courses: instruction that motivates learning. $1^{\text {st }}$ edn. San Francisco: Jossey-Bass.

Yorke, M. and Knight, P. (2004) 'Self-theories: some implications for teaching and learning in higher education', Studies in Higher Education, 29(1), pp. 25-37.

\section{Author details}

Dr Jane MacKenzie is Head of Academic Practice at the Learning and Teaching Centre, University of Glasgow. As well as contributing to a postgraduate certificate in academic practice, which is a required qualification for all new lecturers and teachers at the university, she works in collaboration with academics around campus to design new curricula, implement changes in assessment practices and encourage student retention initiatives. Her research focuses on the role of community and collaboration in staff and student engagement with learning and teaching, and the definition, understanding, implementation, recognition and reward of the Scholarship of Teaching and Learning.

Dr Jane Pritchard has worked in academic development for over 12 years, both in the UK and Canada. Jane is currently working for the University of Bristol as an academic staff developer with teaching and learning remit across the university. Currently she has been charged with redesigning the teaching and learning programmes to include a CPD framework for academic practice across the range of academic and support services profiles. Her research interests range from engaging and 
supporting the scholarship of teaching and learning and unpacking its meaning in practice, to engaging students in enquiry-based learning opportunities through their studies. 